\title{
DZIAŁALNOŚĆ POLSKIEGO INSTYTUTU NAUKOWEGO W LATACH 1942-1989
}

\section{Bartosz NOWOŻYCKI (Warszawa)}

\section{ORGANIZACJA I DZIAŁALNOŚĆ PIASA W LATACH 1942-1945}

\subsection{Powstanie PIASA}

W 1941 r. prof. Rafał Taubenschlag, jeden z członków Polskiej Akademii Umiejętności (PAU) w Krakowie znajdujących się na emigracji, wystąpił do Ministerstwa Spraw Wewnętrznych Rządu RP na Uchodźstwie z projektem powołania placówki PAU na uchodźstwie. Placówka ta, będąca pod patronatem rządu londyńskiego, miała być autonomiczną instytucją kulturalno-naukową, która stanowiłaby ,pomost” pomiędzy nauką polską i amerykańską ${ }^{1}$. W swych założeniach projekt zakładał, iż placówka PAU będzie koordynowała badania naukowe prowadzone przez Polaków przebywających w USA. Zakładano również, że stanie się ona największym ośrodkiem wydawniczym, archiwalnym oraz biblioteką umożliwiającą Polakom badania naukowe podczas wojny oraz po jej zakończeniu ${ }^{2}$. Pod koniec 1941 r. Komitet Organizacyjny w składzie: Oskar

\footnotetext{
${ }^{1}$ The Origin and Work of the Organizing Committee, Bulletin of the Polish Institute of Arts and Sciences in America (dalej: Bulletin PIASA) 1942 nr 1, s. 9-11.

${ }^{2}$ Polski Instytut Naukowy $w$ Ameryce, oprac. S. Flis, Warszawa 2004, s. 12-13; 50 th Anniversary 1942-1992, New York 1992, s. 24-25.
} 
Halecki, Jan Kucharzewski, Wacław Lednicki, Bronisław Malinowski, Wojciech Świętochowski oraz Rafał Taubenschlag przy współpracy Fundacji Kościuszkowskiej, rozpoczął przygotowania do powołania Instytutu Naukowego stanowiącego kontynuację PAU. Starano się wówczas dotrzeć do amerykańskiego świata naukowego, pozyskać wsparcie organizacji polonijnych, przygotowywano podstawy prawne dla Instytutu oraz starano się o pieniądze niezbędne do jego działalności ${ }^{3}$. Wspominani wyżej uczeni polscy przebywający na emigracji czuli moralny obowiązek aby połączyć wysiłki w celu zachowania polskiej nauki i kultury, tak zawzięcie niszczonej przez okupantów ${ }^{4}$.

W 1942 r. rząd londyński zatwierdził statut Instytutu i przeznaczył subsydia na jego działalność ${ }^{5}$. Prezesem został mianowany Bronisław Malinowski, powołano także dwudziestosześcioosobową Radę Instytutu ${ }^{6} .1$ maja 1942 r. Polski Instytut Naukowy (PIN/PIASA) został zarejestrowany, również dzięki wstawiennictwu rządu londyńskiego jako stowarzyszenie niedochodowe, naukowe oraz apolityczne działające na terytorium USA z siedzibą w Nowym Yorku ${ }^{7}$. Instytut otrzymał siedzibę w kamienicy na Manhattanie na 36 Ulicy - pod numerem $37^{8}$.

Statut Polskiego Instytutu Naukowego w Ameryce (autonomicznej stacji PAU) określał, iż rolą Instytutu jest podtrzymanie, rozwój oraz propagowanie polskiej nauki i kultury w Stanach Zjednoczonych. PIASA miała w swych założeniach stanowić płaszczyznę współpracy i wzajemnej wymiany między polskim a amerykańskim społeczeństwem. Instytut wedle statutu był niezależnym centrum badawczym wspierającym polskich badaczy, naukowców oraz twórców kultury. Siedzibą Instytutu był Nowy Jork, zaś terenem działania całe Stany Zjednoczone Ameryki Północnej ${ }^{9}$. Swoje cele PIASA miała realizować w ramach:

- organizowania wykładów, konferencji i odczytów,

- $\quad$ stworzenia centrum badawczego w postaci archiwum i biblioteki ${ }^{10}$,

- a także prowadzenia działalności wydawniczej ${ }^{11}$.

Kierownictwo Instytutu sprawowała Rada (urzędowo z Ambasadorem RP w Waszyngtonie) oraz wybrany spośród niej prezes. Natomiast Zarząd Instytutu składał się z dyrektora i jego zastępcy oraz kierowników poszczególnych sekcji. Rada Instytutu sprawowała pieczę nad jego statutową działalnością oraz budżetem, do jej kompetencji należało także zatwierdzanie sprawozdań Zarządu. Zarząd kierował pracami Instytutu oraz jego sekcji (badań historyczno-politycznych, badań prawa oraz problemów gospodarczo-społecznych), przygotowywał także budżet. Dyrektor Instytutu kierował archi-

\footnotetext{
${ }^{3}$ Archiwum PIASA, collection 017, folders 142-146, T. Gromada, ,Rola i działalność PINu podczas Zimnej Wojny”, mps., brak daty i numeracji stron oraz korespondencja dotycząca powołania PIASA.

${ }^{4}$ S. Strzetelski, The Polish Institute of Arts, s. 4; 50 th Anniversary 1942-1992, s. 24-25.

${ }^{5}$ Tenże, The Polish Institute of Arts, s. 6; 50 ${ }^{\text {th }}$ Anniversary 1942-1992, s. 24.

${ }^{6}$ Polski Instytut Naukowy w Ameryce, s. 14; D. S. Wandycz, Polski Instytut Naukowy w Ameryce: $w$ trzydziesta rocznicę: 1942-1972, New York 1974, s. 15-16.

${ }^{7}$ S. Strzetelski, The Polish Institute of Arts, s. 5.

${ }^{8}$ The Origin and Work of the Organizing Committee, s. 11.

9 Archiwum PIASA, collection 017, folders 145, „Projekt Statutu Polskiego Instytut Naukowego w Stanach Zjednoczonych".

${ }^{10}$ Założenie biblioteki i archiwum w Instytucie umożliwiło zebranie wartościowego księgozbioru oraz archiwaliów. Ocalono w ten sposób liczne książki i dokumenty; Polski Instytut Naukowy w Ameryce, s. 25.

${ }_{11}$ Archiwum PIASA, collection 017, folders 5, „Statute of the Polish Institute of Arts and Sciences in America".
} 
wum, biblioteką oraz działalnością popularyzatorską i wydawniczą ${ }^{12}$. Raz w roku miały odbywać się zjazdy członków PIN-u, na których zatwierdzano sprawozdania Rady, Zarządu oraz Komisji Rewizyjnej.

W kolejnych latach wraz z rozwojem Instytutu dokonywano zmian w jego Statucie, najważniejsze z nich miały miejsce w latach $1965-1974^{13}$. Wówczas zmianie uległ sposób wyboru prezesa, Zarządu i Rady, o wyborze tychże decydowało walne zgromadzenie. Zarząd spośród swoich członków wyłaniał: dyrektora, sekretarza, sekretarza generalnego, skarbnika oraz redaktora kwartalnika wydawanego przez Instytut — „The Polish Review”. Zarząd otrzymał funkcję nadrzędną i nadzorczą, miał także zbierać się co najmniej cztery razy w roku. W przerwach między sesjami Zarządu jego funkcje pełnił Komitet Wykonawczy w składzie: prezes, dwóch wiceprezesów, dyrektor, sekretarz oraz skarbnik ${ }^{14}$.

Polski Instytut Naukowy w Ameryce pierwotnie zrzeszał naukowców pochodzących z Polski, którzy w wyniku II wojny światowej znaleźli się na emigracji w USA ${ }^{15}$. W latach 60. XX w. członkami Instytutu zostawali także naukowcy polskiego pochodzenia urodzeni w USA ( $\mathrm{w}$ tym dzieci i wnuki polskiej emigracji z początku XX w.), a także Amerykanie związani swoimi zainteresowaniami badawczymi z Polską ${ }^{16}$. W latach 70. XX w. Instytut zmienił swój charakter, odszedł od wizerunku polskiego towarzystwa emigracyjnego, a zaczął funkcjonować jako niezależna instytucja amerykańska — co znacznie wpłynęło na jego umiejscowienie w amerykańskich kręgach naukowych i akademickich ${ }^{17}$.

\subsection{Działalność PIASA w okresie 1942-1945}

W okresie II wojny światowej Instytut realizował dwa główne cele: pierwszym było prowadzenie badań naukowych i działalności kulturalnej niemożliwej w okupowanej Polsce - aby w przyszłości badania te mogły stanowić podstawę do dalszej pracy naukowej w wolnym Kraju, drugi zaś polegał na propagowaniu polskiej nauki i kultury w społeczeństwie amerykańskim oraz umacnianiu relacji między Polską a USA ${ }^{18}$.

${ }^{12}$ Członkowie Rady oraz dyrektor wraz z wicedyrektorem wybierani byli przez ogół członków PIN-u na trzyletnią kadencję. W przypadku likwidacji Instytutu jego majątek przechodził w ręce PAU; Archiwum PIASA, collection 017, folders 145, „Projekt Statutu Polskiego Instytut Naukowego w Stanach Zjednoczonych".

${ }^{13}$ By-Laws of The Polish Institute of Arts and Science in America, The Polish Review 1973 wol. $18 \mathrm{nr}$ 4, s. 123-192.

${ }^{14}$ Polski Instytut Naukowy w Ameryce, s. 15.

${ }^{15}$ Wśród członków PIASA znaleźli się m.in.: Isaac Bashevis Singer, Zbigniew Brzeziński, Kazimierz Funk, Ludwik Gross, Oskar Halecki, Jan Karski, Jerzy Kosiński, Jan Lechoń, Bronisław Malinowski, Czesław Miłosz, Artur Rubinstein, Kazimierz Wierzyński oraz Józef Wittlin; The Polish Institute of Arts and Sciences of America, s. 11.

${ }^{16}$ Wedle statystyk z 1969 r. około 45\% członków PIASA urodziło się w USA, a około 55\% w Polsce i Europie. Większość z nich (około 55\%) była w wieku pomiędzy 40 a 60 lat. Większość członków PIASA (57\%) rozlokowana była we wschodnich stanach, zaś około $28 \%$ na środkowym zachodzie, a około $14 \%$ na zachodzie i północy USA; D. S. Wandycz, Register of Polish American Scholars, Scientists, Writers \& Artists, New York 1969, s. 5-9.

${ }^{17}$ Archiwum PIASA, collection 017, folders 142-146, T. Gromada, „Rola i działalność PINu podczas Zimnej Wojny", mps.

${ }^{18}$ Instytut starał się prowadzić możliwie szeroką działalność naukową, aby zachować wszelką podstawę do odtworzenia życia kulturalno-naukowego w Polsce; S. Strzetelski, The Polish Institute of Arts, s. 8. 
PIN wydawał książki i prace naukowe, nakładem Instytutu ukazywał się także kwartalnik „Bulletin of the Polish Institute of Arts and Sciences in America”" ${ }^{\text {. Biule- }}$ tyn PIN-u miał zastąpić na okres wojny międzynarodowy „Bulletin of the Polish Academy", który docierał do najważniejszych bibliotek i ośrodków naukowych za granicą. Nowy biuletyn był kroniką PIN-u, zawierał także publikowane w całości lub w wyjątkach prace naukowe polskich badaczy oraz wykłady i wystąpienia osób związanych z Instytutem. Zakładano, iż po zakończeniu II wojny światowej rola Instytutu, tym samym jego biuletyny, zostanie ograniczona do promowania polskiej kultury i nauki w USA, oraz do podtrzymywania współpracy polsko-amerykańskiej ${ }^{20}$. Biuletyn ukazywał się nakładem PIASA do 1946 r., wydano 12 numerów (3100 stron tekstu) zawierających 206 artykułów naukowych ${ }^{21}$.

Poza wydawnictwami PIASA organizowała w latach 1942-1945 konferencje i sesje naukowe, poświęcone w dużej mierze kwestii odbudowy Polski po zakończeniu wojny $^{22}$. Zaczęto także pozyskiwać pierwsze zbiory archiwalno-biblioteczne. Działalność Instytutu umożliwiła zachowanie i wzbogacenie dorobku naukowego i kulturalnego polskich badaczy, przyczyniła się również do nagłośnienia sprawy polskiej wśród społeczeństwa amerykańskiego $^{23}$.

Instytut nie ograniczał się jedynie do Nowego Jorku, powołano placówki w Kanadzie (Montreal) ${ }^{24}$ oraz w środkowo-zachodnich stanach (Chicago) ${ }^{25}$. Współpracowano również z wieloma polskimi organizacjami m.in. w USA, Wielkiej Brytanii, Francji, Brazylii, Chile, Meksyku, Wenezueli, Urugwaju oraz w Libanie ${ }^{26}$.

Istotny wpływ na działalność PIASA miały postanowienia konferencji w Teheranie, Jałcie i Poczdamie. Członkowie Instytutu nie pozostali obojętni wobec losów powojennej Polski, zdawali sobie także sprawę z faktu, iż nie będzie ona niepodległym i demokratycznym krajem ${ }^{27}$. Cofnięcie uznania dla Rządu RP na Uchodźstwie zagroziło istnieniu Instytutu, tym bardziej, że w Polsce reaktywowano zależny od rządu komunistycznego PAU. PIASA odżegnała się od jakiejkolwiek współpracy i pomocy ze strony władz PRL, unikano również wszelkich kontaktów z ich przedstawicielami. Mimo tych trudności podjęto decyzję o kontynuacji pracy na emigracji. Instytut wyra-

${ }^{19}$ Patrz wykaz publikacji PIASA oraz artykułów w „Bulletin PIASA”; S. Strzetelski, The Polish Institute of Arts, s. 37-48.

${ }^{20}$ The Founding of The Institute, Bulletin PIASA, 1942 nr 1, s. 7-8.

$2150^{\text {th }}$ Anniversary 1942-1992, s. 27.

${ }^{22}$ Patrz więcej: Bulletin PIASA za lata 1943-1946. W latach 1943-1944 PIASA zorganizowała 93 wykłady; Archiwum PIASA, collection 017, folders 1, „Procedings of The Annual Meeting of the PIASA", s. 2-3.

${ }^{23}$ Prowadzono także od 1944 r. rejestr poloników w bibliotekach i uniwersytetach amerykańskich; Polski Instytut Naukowy w Ameryce, s. 26.

${ }^{24}$ Appendix By-laws of the Canadian Branch of PIASA, Bulletin PIASA 1944 nr 4, s. 911912; Organization of the Canadian Branch, Bulletin PIASA 1944 nr 3, s. 605-607; Archiwum PIASA, collection 017, folder 1, ,Regulamin Oddziału Kanadyjskiego”.

${ }^{25}$ Organization of the Midwest Branch, Bulletin PIASA 1944 nr 1, s. 12-13.

${ }^{26}$ S. Strzetelski, The Polish Institute of Arts, s. 10 oraz General Development of The Institute, Bulletin PIASA 1943, nr 1, s. 5-6; Archiwum PIASA, collection 017, folders 1, „General Development of the Institute".

27 Archiwum PIASA, collection 017, folders 142-146, T. Gromada, „Rola i działalność PINu podczas Zimnej Wojny”, mps.; $50^{\text {th }}$ Anniversary 1942-1992, New York 1992, s. 27-28. 
ził sprzeciw wobec komunistycznych rządów w Polsce i odmówił uznania zwierzchności odtworzonej PAU ${ }^{28}$.

Istotnym problemem stało się utrzymanie PIASA, gdyż same składki członkowskie i dotacje nie pokrywały jej potrzeb finansowych i ograniczały możliwości szerszego działania. Cofnięcie uznania przez aliantów dla rządu londyńskiego niosło ze sobą także utratę rządowych dotacji ${ }^{29}$. Instytut stracił również swą dotychczasową siedzibę, biura Instytutu przeniesiono do wynajmowanych pomieszczeń przy 35 Ulicy, a wykłady organizowano w Woodrow Wilson Foundation Library ${ }^{30}$. Instytut rozpoczął poszukiwanie nowych źródeł finansowania swojej działalności, ograniczając jednocześnie wydatki $^{31}$. Środki finansowe pozyskiwano od fundacji i instytucji polonijnych, poprzez składki członkowskie i donacje oraz darowizny od sympatyków PIASA i Polski (również wśród społeczeństwa amerykańskiego) ${ }^{32}$.

\section{DZIAŁALNOŚĆ PIASA W OKRESIE 1945-1989}

\subsection{Lata 1946-1956}

Trudna sytuacja materialna oraz zmiany polityczne, wywołane postanowieniami konferencji pokojowych kończących II wojnę światową, odbiły się negatywnie na działalności Polskiego Instytutu Naukowego w Nowym Jorku. Rzeczywistość powojenna, szczególnie w zniewolonej i odciętej od Zachodu Polsce, różniła się znacznie od tej, której oczekiwano. Większość emigracyjnych uczonych i pisarzy podjęło decyzję o pozostaniu w USA, kontynuowanie tu pracy naukowej i artystycznej oraz współpracy z PIASA ${ }^{33}$. Instytut nie mógł dostatecznie włączyć się w pomoc dla polskiej kultury i nauki. Szczęśliwie PIASA miała wielu przyjaciół pośród polskich i amerykańskich organizacji, jak i osób prywatnych, które wspierały jej działania. Wielką pomocą były dotacje otrzymywane od 1946 do 1951 r. od Kongresu Polonii Amerykańskiej, lecz przez kolejne cztery lata Instytut musiał polegać jedynie na donacjach i składkach członkowskich $^{34}$. Wyzwaniem była pomoc w odbudowie zniszczonego przez wojnę życia kulturalnego, wsparcie dla emigracyjnej nauki i sztuki, jak również osobom uznanym za „wrogie” przez władze komunistyczne w Polsce ${ }^{35}$. PIASA przyjęła także rolę ,,wolnego głosu nauki i sztuki”, który przeciwstawiał się zniewolonej i zindoktrynowanej działalności polskich ośrodków kulturalno-naukowych ${ }^{36}$.

\footnotetext{
${ }^{28}$ Archiwum PIASA, collection 017, folders 142-146, T. Gromada, „Rola i działalność PINu podczas Zimnej Wojny", mps.

${ }^{29}$ Report on the Activities of the Institute 1945-1946, Bulletin PIASA, 1945-1946 wol. 4, s. $7-8$.

${ }^{30}$ Tamże, s. 9.

${ }^{31}$ General Development of the Institute, Bulletin PIASA, 1944 wol. 3 nr 3-4, s. 425-426.

32 Archiwum PIASA, collection 017, folders 142-146, T. Gromada, „Rola i działalność PINu podczas Zimnej Wojny", mps. W okresie 1942-1945 osobą, która miała największy wpływ na rozwój i działalność PIASA był Oskar Halecki.

${ }^{33} 50^{\text {th }}$ Anniversary 1942-1992, s. 28.

${ }^{34}$ S. Strzetelski, The Polish Institute of Arts, s. 13.

${ }^{35}$ Report on the Activities of the Institute 1945-1946, s. 10.

${ }^{36}$ The Twenty-Fifth Anniversary of The Polish Institute, The Polish Review 1968 wol. 13 nr 2, s. 107.
} 
Mimo ogromnych trudności PIASA i jej placówki nie przerwały działalności, prowadzono badania naukowe, publikowano książki, organizowano różnego rodzaju imprezy kulturalno-naukowe (niektóre sponsorowano), starano się również pomagać badaczom i artystom w kraju. W 1946 r. opublikowano (lub sponsorowano) następujące prace: B. Świtalski, Neoplatonism and the Ethics of St. Augustine, M. Haiman, Kosciuszko - Leader and Exile (t. 2) ${ }^{37}$, L. Stenz The Climate of Afganistan: its Aridity, Dryness and Divisions, Z. Krzywobłocki Application of Double Fourier Series to the Calculation of Stresses Caused by Pure Bending in a Circular Monocoque Cylinder with a $\mathrm{Cut}$-Out ${ }^{38}$. Przez kolejne lata istnienia Instytutu każdy z członków PIASA kontynuował swoje prace badawcze, dawał wykłady, uczestniczył w konferencjach i publikował prace naukowe. PIASA miała aktywny udział w amerykańskim życiu akademickim, swój wkład w amerykańską muzykę i sztukę, edukację, badania laboratoryjne i kliniczne itp. Skupieni w PIASA naukowcy i artyści stali się częścią amerykańskiej kultury i nauki ${ }^{39}$.

W kwestii wsparcia ,przymusowych” emigrantów oraz instytucji polonijnych działających w USA Instytut mógł służyć jedynie pośrednictwem i wsparciem merytorycznym $^{40}$. Do polskich ośrodków akademickich i bibliotek Instytut wysłał, przy częściowej pomocy Smithsonian Institution, kilka skrzyń z książkami i periodykami naukowymi, zawierającymi dorobek naukowy opublikowany w czasie wojny w Kanadzie i USA. W lecie 1946 r. rozpoczęto zbiórkę funduszy na paczki (C.A.R.E.) dla polskich naukowców, które zawierały żywność oraz ubrania ${ }^{41}$. PIASA, mimo założeń programowych, nie mogła do końca odciąć się od zagadnień politycznych oraz praw człowieka. Oskar Halecki zabrał w 1947 r. głos w imieniu PIASA w trzech ważnych konferencjach: The Conference on the Declaration of Human Rights, The University and Its Word Responsibilities oraz The Conference on International Educational Reconstruction $^{42}$. Instytut uczestniczył $\mathrm{w}$ badaniach nad Europejskim ruchem federalistycznym, organizował także spotkania z uczonymi z Ukrainy, Czech, Litwy oraz pochodzenia żydowskiego ${ }^{43}$.

W okresie od 1949 do 1950 r. PIASA wydała 28 listów i memorandów na temat sytuacji w Polsce, które poprzez Kongres Polonii Amerykańskiej dotarły do amerykańskich mediów. Rozsyłano materiały dotyczące polskiej historii i literatury do organizacji polonijnych oraz amerykańskich ośrodków naukowych. Wysłano także sześć paczek do kraju zawierających ubrania, prócz tego około sto książek. Zorganizowano również kilkanaście wykładów, prowadzono także prace badawcze, z których warto wspomnieć o badaniach J. Kucharzewskiego nad relacjami USA-Rosja ${ }^{44}$.

W latach 1951-1952 sytuacja finansowa PIASA stała się dramatyczna. Rok 1952 był niezmiernie ciężki dla Instytutu, gdyż rok wcześniej Kongres Polonii Amerykań-

${ }^{37}$ Pierwszy tom biografii pt. Kościuszko in the American Revolution ukazał się w 1943 r.

${ }^{38}$ Archiwum PIASA, collection 017, folders 3, list Oskara Haleckiego z 10 maja 1947.

${ }^{39}$ Chronicles of the Polish Institute, The Polish Review 1977 wol. 22 nr 1, s. 78.

${ }^{40}$ Niewielkie zasoby finansowe starczyły jedynie na dwie studolarowe dotacje dla organizacji samopomocowej polskich studentów w Brukseli oraz dla polskich badaczy tworzących kolekcję etnograficzną i antropologiczną w północnej Rodezji.

${ }^{41}$ Największego wsparcia dla tej akcji udzieliła Federation of Newman Clubs; Report on the Activities of the Institute 1945-1946, s. 11.

$4250^{\text {th }}$ Anniversary 1942-1992, s. 29.

${ }^{43}$ S. Strzetelski, The Polish Institute of Arts, s. 14, 22.

${ }^{44}$ Archiwum PIASA, collection 017, folders 4, list Oskara Haleckiego z 1 marca 1950. 
skiej wstrzymał swoje dotacje. Rozpoczęto szeroko zakrojoną akcję zbierania funduszy przeznaczonych na działalność Instytutu ${ }^{45}$. Poszukując możliwości zapewnienia Instytutowi stałego dochodu powołano wówczas Association of Friends of the Institute ${ }^{46}$. Odczyty i wykłady organizowano jedynie dwa razy w miesiącu, akcję wydawniczą prowadzono w ograniczonym stopniu. Członkowie PIASA wzięli natomiast udział w obchodach 200-lecia Uniwersytetu Columbia ${ }^{47}$.

Wraz ze zbliżającą się powoli rocznicą śmierci Adama Mickiewicza członkowie PIASA, z myślą o popularyzacji jego twórczości w społeczeństwie amerykańskim, powołali w 1953 r. specjalny komitet organizacyjny. W międzyczasie w 1954 r. PIASA zorganizowała trzy ważne wieczory literackie ze znanymi polskimi poetami (członkami PIASA), byli to Jan Lechoń, Kazimierz Wierzyński oraz Józef Wittlin ${ }^{48}$. Wynikiem pracy komitetu organizacyjnego obchodów rocznicy śmierci Adama Mickiewicza była seria sympozjów, wykładów oraz wystaw w 1955 r., które odbyły się w amerykańskich centrach akademickich. Najważniejszym wydarzeniem była konferencja 20 listopada 1955 r. w Hunter College w Nowym Jorku. Brało w niej udział 2500 osób, zaś referaty $\mathrm{z}$ tej konferencji opublikowano w zbiorze Adam Mickiewicz in World Literature ${ }^{49}$. Dodatkowo w tym roku PIASA powołała komitet obchodów 100-lecia urodzin prezydenta USA Woodrowa Wilsona. W kwietniu zorganizowano wspólnie z amerykańskimi uczonymi sesję naukową poświęconą prezydentowi Wilsonowi, opublikowano także pracę naukową Wilson and Poland ${ }^{50}$.

Wydarzenia Października 1956 r. w Polsce oraz napływ fali nowych emigrantów do USA zamknęły powojenny okres działalności Polskiego Instytutu Naukowego w Nowym Jorku. W tym okresie Instytut działał aktywnie na polu pomocy Polsce: zaopatrywano biblioteki i ośrodki akademickie w książki i periodyki, udzielano wsparcia finansowego oraz ułatwiano kontakt $\mathrm{z}$ amerykańską nauką ${ }^{51}$. Udało się przy wsparciu Fundacji Alfreda Jurzykowskiego zakupić dom, który stał się nową siedzibą PIA$\mathrm{SA}$, a także zrealizować marzenie o stworzeniu wyspecjalizowanej biblioteki ${ }^{52}$.

\subsection{Lata 1956-1968}

Po 14 latach istnienia PIASA zyskała reputację wiodącej polskiej instytucji kulturalnej o szerokim polu działalności i wielu znakomitych członkach. Cieszyła się wsparciem Polonii oraz amerykańskiego społeczeństwa. Największym problemem z jakim zmagał się Instytut był brak stałych środków finansowych na regularną działalność.

${ }^{45} 50^{\text {th }}$ Anniversary 1942-1992, s. 30.

${ }^{46}$ Odbyło się to przy współpracy Polish National Alliance of Brooklyn; S. Strzetelski, The Polish Institute of Arts, s. 15.

${ }^{47}$ Polski Instytut Naukowy w Ameryce, s. 17-18; Archiwum PIASA, collection 017, folder 5, list Oskara Haleckiego z maja 1951.

${ }^{48} 50^{\text {th }}$ Anniversary 1942-1992, s. 31.

49 Archiwum PIASA, collection 017, folder 5, „,Report on the activities of PIASA from 15 May 1954 to 30 April 1955".

${ }^{50}$ Archiwum PIASA, collection 017, folder 8, list Stanisława Strzetelskiego z 28 maja 1955; Archiwum PIASA, collection 017, folder 10, „Report of the Director of PIASA for the Period 1.05.1956-30.03.1957”.

${ }^{51}$ The Twenty-Fifth Anniversary of the Polish Institute, The Polish Review 1968 wol. 13 nr 2, s. 108.

${ }_{52} 50^{\text {th }}$ Anniversary 1942-1992, s. 32. 
Pomoc, którą otrzymywał od instytucji, osób prywatnych i członków, pokrywała wydatki związane z utrzymaniem Instytutu oraz bieżącą (czasem doraźną) pracą. Duże znaczenie dla PIASA miało uznanie w amerykańskim świecie naukowym oraz przychylna postawa społeczeństwa amerykańskiego (w tym Polonii). Dlatego też Instytut aktywnie uczestniczył w życiu kulturalno-naukowym publikując prace naukowe oraz prowadząc działalność popularyzatorską w postaci wystaw, wykładów i konferencji ${ }^{53}$.

W latach 1956-1957 Instytut kontynuował swoją programową działalność, obejmującą: prace wydawnicze, informowanie Polonii oraz amerykańskiej opinii publicznej o sytuacji w Polsce, organizował spotkania oraz wykłady dla polskich naukowców i pisarzy ${ }^{54}$. Od 1956 r. rozpoczęto także porządkowanie i scalanie biblioteki Instytutu rozrzuconej po wielu lokalach w Nowym Jorku, Trenton, New Jersey ${ }^{55}$. Dopiero w 1959 r., dzięki wynajęciu dodatkowych pomieszczeń, możliwe było scalenie zbiorów PIASA. W owym czasie nie istniała w USA specjalistyczna biblioteka umożliwiająca badania nad Polską i jej historią, dlatego też rozwój biblioteki PIASA był jednym z najważniejszych przedsięwzięć na przyszłość. Gwałtowny rozrost biblioteki w 1956 r., związany z wymianą wydawnictw z krajem oraz napływem licznych kolekcji archiwalnych i księgozbiorów, był dla Instytutu wyzwaniem. Konieczne było nadanie zbiorom PIASA określonego profilu oraz dokonanie selekcji książek. Rozpoczęto pracę nad stworzeniem nowego układu biblioteki i rozdzielenia jej od archiwum ${ }^{56}$.

Odwilż po wydarzeniach październikowych 1956 r. umożliwiła, pierwszy raz od zakończenia wojny, szerszy kontakt z polskimi środowiskami naukowymi. Możliwość tą wykorzystano wysyłając do kraju książki i periodyki. Fundowano także stypendia dla badaczy i studentów oraz udzielano doraźnej pomocy finansowej ${ }^{57}$. Od $1956 \mathrm{r}$. Instytut prowadził także akcję „Operation: Books for Poland”, polegającą na systematycznym wysyłaniu książek naukowych oraz literatury pięknej do polskich bibliotek i ośrodków akademickich ${ }^{58}$. Działania PIASA, z czasem coraz lepiej koordynowane, nie mogły pokryć ,głodu wiedzy” polskich uczonych i artystów ${ }^{59}$. O skali potrzeb świadczą chociażby listy z Polski zawierające prośby o nadesłanie książek oraz periodyków — w 1957 r. Instytut otrzymał ponad 2000 takich listów. Instytut służył także jako centrum informacji naukowej i bibliograficznej ${ }^{60}$. W odpowiedzi na akcję PIASA zaczęły napływać książki i periodyki wydawane w kraju. Do 1960 r. na program pomocy Polsce przeznaczono około 200 tys. dolarów ${ }^{61}$.

W 1956 r. PIASA rozpoczęła wydawanie nowego kwartalnika „The Polish Review”, który miał zastąpić wychodzący w latach 1942-1946 „Bulletin of the Polish

${ }^{53}$ Do 1960 r. PIASA wydała 18 publikacji, 11 numerów „Bulletin PIASA” oraz 12 numerów „The Polish Review”. W przygotowaniu były prace naukowe; S. Strzetelski, The Polish Institute of Arts, s. 16, 37.

${ }^{54}$ Niezależna akcja informacyjna był szczególnie ważna w czasie wydarzeń w 1956 r., każdy numer „The Polish Review” zawierał kronikę wydarzeń w Polsce.

${ }^{55}$ Polski Instytut Naukowy w Ameryce, s. 27.

56 Archiwum PIASA, collection 017, folder 10, „Report of the Director of PIASA for the Period 1.05.1956-30.03.1957".

${ }^{57}$ Chronicles of the Polish Institute, The Polish Review, 1975 wol. 20 nr 1, s. 155-157.

${ }^{58}$ Report on the activities of the Polish Institute of Arts and Sciences in America, for the period 1956/1957, The Polish Review 1957 wol. 2 nr 2-3, s. 177.

59 Archiwum PIASA, collection 017, folder 10, ,Report of the Director of PIASA for the Period 1.05.1956-30.03.1957".

${ }^{60}$ S. Strzetelski, The Polish Institute of Arts, s. 19.

${ }^{61} 50^{\text {th }}$ Anniversary 1942-1992, s. 32-34. 
Institute of Arts and Sciences in America"62. Wznowienie czasopisma drukowanego w języku angielskim dawało Instytutowi możliwość szerszego oddziaływania w USA. Nowy kwartalnik miał być obiektywnym źródłem informacji dotyczącym polskiej nauki oraz kultury, a także miał stanowić możliwość publikowania w „wolnym świecie" polskim uczonym i pisarzom ${ }^{63}$. W swoich założeniach miał być również poświęcony analizie bieżącej sytuacji w Polsce ${ }^{64}$. „The Polish Review” umożliwiał zabieranie głosu na temat historii i bieżącej sytuacji w Polsce, dał także możliwość zaistnienia polskim badaczom i pisarzom w amerykańskim świecie akademickim ${ }^{65}$. Renomę „The Polish Review" w amerykańskim świecie naukowym ukazywała wzrastająca liczba amerykańskich autorów nadsyłających swoje teksty do redakcji. „The Polish Review” ukazuje się nakładem PIASA do dnia dzisiejszego, mimo jego interdyscyplinarności jest całkowicie poświęcony zagadnieniom związanym z Polską, jej kulturą i historią ${ }^{66}$. Ważnym wówczas wydarzeniem dla „The Polish Review” był udział w dyskusji dotyczącej granicy polskiej na Odrze i Nysie (oraz zwalczaniu antypolskiej propagandy), która rozpętała się po opublikowaniu przez Elizabeth Wiskemann książki Germany's Eastern Neighbors ${ }^{67}$.

W 1958 r. PIASA podjęła dalsze wysiłki zmierzające do udzielenia pomocy polskiej nauce. W oparciu o informacje płynące z Polski możliwe było ukierunkowanie wysiłków oraz odpowiedzenie na konkretne zapotrzebowanie. Udało się zorganizować akcję niesienia pomocy polskiej medycynie, wysyłano fachową literaturę, sprzęt medyczny oraz laboratoryjny ${ }^{68}$. Niestety akcja ta z powodu braku odpowiednich funduszy nie mogła być zakrojona na szeroką skalę. Wielu uczonych z Polski dzięki pośrednictwu PIASA mogło zaprezentować swoje badania w amerykańskim świecie naukowym, ufundowano także kilkadziesiąt stypendiów ${ }^{69}$. Wsparcie dla Polski było możliwe dzięki funduszom otrzymanym od licznych organizacji i osób prywatnych ${ }^{70}$.

Rok 1959 był okresem znacznego rozwoju PIASA oraz zwiększenia aktywności na wielu polach swojej działalności. Od października 1959 r. Instytut rozpoczął przygotowania do obchodów 1000-lecia chrztu Polski. Na Uniwersytecie Fordham zorganizowano konferencję naukową dotyczącą chrztu Polski ${ }^{71}$. W sumie w latach 1956-1960 PIASA zorganizowała 31 odczytów oraz 22 sympozja dyskusyjne. Dzięki życzliwości Fundacji Alfreda Jurzykowskiego (zachowała ona tytuł własności do budynku) możli-

${ }^{62}$ S. Strzetelski, The Polish Institute of Arts, s. 17. Powstanie „The Polish Review” było w dużej mierze zasługą Stanisława Strzetelskiego, odegrał on również ważną rolę przy organizowaniu programu pomocy Polsce w latach 1956-1960.

${ }^{63}$ Polski Instytut Naukowy w Ameryce, s. 18.

${ }^{64}$ Foreword, The Polish Review 1956 wol. 1 nr 1, s. 2.

${ }^{65}$ The Twenty-Fifth Anniversary of the Polish Institute, The Polish Review, 1968 wol. 13 nr 2, s. 105.

${ }^{66}$ Fifty Years of Polish Scholarship: The Polish Review 1956-2006, New York 2006, s. 1-5.

${ }^{67}$ Notes, The Polish Review 1956 wol. 1 nr 4, s. 107-118.

${ }^{68}$ Do marca 1958 r. wysłano ponad 6 tys. książek do Polski; Archiwum PIASA, collection 017, folder 11, „Program of Cultural Assistance to Poland”.

69 Archiwum PIASA, collection 017, folder 11, „Program of Cultural Assistance to Poland”; tamże, ,Medical Aid to Poland”.

${ }^{70}$ Należy tu wymienić chociażby: Charles E. Merrill Trust, Appleton-Century-Crofts, The Library of the Council on Foreign Relations, Hogram Merrill Foundation oraz osoby prywatne: A. Jurzykowski, T. Sendzimir, Wanda Roehr, S. Nowak, Ch. E. Merrill; S. Strzetelski, The Polish Institute of Arts, s. 20.

${ }^{71}$ Tamże. 
we było w 1960 r. zakupienie dla PIASA nowej siedziby przy 66 Ulicy $^{72}$. Nową siedzibę otwarto 1 sierpnia 1960 r., znalazły się w niej pomieszczenia przeznaczone na bibliotekę i archiwum oraz na salę wykładową ${ }^{73}$.

W latach 1961-1962 do PIASA nadal napływały książki z polskich bibliotek i instytucji naukowych, a Instytut kontynuował akcję pomocy dla polskiej nauki ${ }^{74}$. Pozyskiwano również coraz więcej kolekcji od uczonych i artystów z USA. Opublikowano angielskie tłumaczenie Pana Tadeusza Adama Mickiewicza oraz pierwszy tom Millenium Library - The Polish Millenium. W PIASA jak co roku odbywały się wykłady i sesje naukowe, członkowie Instytutu przygotowywali także obchody milenium chrztu Polski $^{75}$. Do 1961 r. (począwszy od 1955 r.) Instytut opublikował następujące prace: J. Wespiec, Polish Institutions of Higher Learning, Polish-Jewish Dialogue; J. Conrad, Centennial Essays; J. Ursyn-Niemcewicz, Essays; K. Wierzyński, Poems; S. Strzetelski, The Polish Institute of Arts and Sciences in America, Early XIX Century American-Polish Music; F. Gross, Social Volumes Studies and Sketches, The Virginia University Conference on Poland since Gomulka; J. Kosinski, Sociology in the US, A. Mickiewicz, Pan Tadeusz oraz pracę o Woodrowie Wilsonie ${ }^{76}$.

Od 1962 r. reaktywowano działalność Oddziału Środkowozachodniego PIASA z siedzibą w Chicago. W tym czasie na Uniwersytecie w Chicago otwarto fakultet The Study of Polish Literature, który miał zintensyfikować badania nad polskim językiem, literaturą oraz kulturą ${ }^{77}$. W badaniach tych brali udział członkowie PIASA ${ }^{78}$. W kolejnym roku w statucie PIASA dokonano znaczących zmian, w skutek których znacznie wzrosła liczba członków Instytutu. Wprowadzono podział na członków stałych i korespondencyjnych, zmieniono również kryteria przyjmowania do PIASA ${ }^{79}$. W 1963 r. bibliotece PIASA, liczącej ponad 15 tys. woluminów, nadano imię Alfreda Jurzykowskiego - wieloletniego dobroczyńcy Instytutu. Pracę nad organizacją i uporządkowaniem księgozbioru Instytutu prowadził bibliotekarz z New York Public Library ${ }^{80}$.

W 1964 r. PIASA kolejny raz opowiedziała się w obronie wolności w komunistycznej Polsce. Udzieliła publicznie poparcia 34 polskim intelektualistom, którzy

72 Archiwum PIASA, collection 017, folder 12, „,Report of the Director of PIASA inc. for. The year 1960".

${ }_{73}$ Polski Instytut Naukowy w Ameryce, s. 19.

${ }^{74}$ Archiwum PIASA, collection 017, folder 90, ,Minutes of the 2-nd Extraordinary Meeting of the Council of PIASA".

75 Archiwum PIASA, collection 017, folder 12, „,Report of the Acting Director of PIASA for the Period 1.10.1961-03.1963".

${ }^{76}$ Archiwum PIASA, collection 017, folder 13, ,Report of Director of the PIASA for Period 01-09.1961".

${ }^{77}$ Wzrosło także zainteresowanie badaczy Polską na Uniwersytetach w Colorado i Buffalo. Przyczyniły się do tego skupiska Polaków w Chicago, Colorado, Kansas oraz w Buffalo; The Polish Review 1962 wol. 7 nr 1, s. 89-92 oraz 1964 wol. 9 nr 1, s. 115-116.

${ }^{78}$ W latach 1962-1963 na Uniwersytecie w Nowym Jorku odbywały się zajęcia z literatury polskiej, pod kierunkiem dr Haliny Wittlin, zaś w latach 1963-1964 na Uniwersytecie British Columbia zorganizowano Polish Studies. Wykłady na temat polskiej i rosyjskiej literatury w 1971 r. prowadzono także na Department of Slavic Languages na Duke University.

${ }^{79}$ Od tej pory członkami PIASA mogli być profesorowie i nauczyciele, uczeni, pisarze i artyści. Kandydaci musieli reprezentować wysoki poziom umiejętności oraz posiadać dwa listy rekomendacji; Archiwum PIASA, collection 017, folder 16, „By-laws of PIASA as approved by the Annual Meeting of Members on 24.03.1962".

${ }^{80} 50^{\text {th }}$ Anniversary 1942-1992, s. 37. 
w liście otwartym skrytykowali rządy Władysława Gomułki w Polsce ${ }^{81}$. Wydano także ważną publikację John F. Kennedy and Poland, zawierającą wybór pism i wypowiedzi prezydenta USA ${ }^{82}$. W tym czasie w ramach PIASA powołano Komitet, którego zadaniem była praca organizacyjna i kancelaryjna.

Podkreśleniem roli Instytutu było przyznanie w latach 1964-1965 wyboru laureatów i organizacji rozdania nagród Alfred Jurzykowski Awards. Były one przeznaczone dla Polaków w uznaniu za wybitne osiągnięcia w dziedzinie nauki i sztuki. Przez kolejne lata Instytut brał dalszy udział w przyznawaniu i organizacji wręczenia Nagród Fundacji Alfreda Jurzykowskiego. Ceremonie wręczenia nagród odbywały się często w siedzibie PIASA, a jej członkowie zasiadali w jury ${ }^{83}$.

W 1000. rocznicę chrztu Polski, w 1966 r., PIASA zorganizowała trzydniowy kongres polskich uczonych z USA i Kanady na Uniwersytecie Columbia ${ }^{84}$. W kongresie brało udział około 500 osób, przedstawiono 135 referatów. Referaty opublikowano w tomie Studies in Polish Civilization ${ }^{85}$. Kolejną dużą konferencję zorganizowano rok później w 25. rocznicę powstania PIASA w New York Public Library w 1967 r. Przygotowywano również do druku rejestr naukowców polskiego pochodzenia z USA i Ka$\operatorname{nady}^{86}$. W tym roku powołano również w ramach Instytutu Sekcję Medyczną.

\subsection{Lata $1968-1989$}

W 1968 r. PIASA za pośrednictwem mediów amerykańskich starała się przeciwdziałać negatywnym reakcjom, jakie wywołała antysemicka kampania w Polsce ${ }^{87}$. Instytut współpracował wówczas przy tłumaczeniu na język angielski książki W. Bartoszewskiego i Z. Lewin The Samaritans: Heroes of the Holocaust ${ }^{88}$. Występowano również publicznie w obronie wolności i praw człowieka w Polsce ${ }^{89}$. Pod koniec lat 60. $\mathrm{XX}$ w. podjęto próby zreformowania biblioteki Instytutu, skatalogowano najcenniejsze

\footnotetext{
${ }^{81}$ Tamże, s. 34.

82 Archiwum PIASA, collection 017, folder 19, „Report of the Director of PIASA for the

${ }^{83}$ Archiwum PIASA, collection 017, folder 20, T. Gromada, „Rola i działalność PINu podczas Zimnej Wojny”, mps.; tamże, „General Report on the Institute activities during the period 24.04.1965-30.04.1966”. Włączenie PIASA w przyznawanie oraz organizację nagród Alfred Jurzykowski Awards było w znacznym stopniu możliwe dzięki staraniom Damiana Wandycza.

84 Przygotowania do uroczystości trwały od 1959 r.; 50 $0^{\text {th }}$ Anniversary 1942-1992, New York 1992, s. 38. Główną rolę w organizacji obchodów 1000-lecia chrztu Polski oraz I Kongresu PIASA w 1966 r. odegrali Oskar Halecki oraz Damian Wandycz.

${ }^{85}$ Archiwum PIASA, collection 017, folder 20, T. Gromada, „Rola i działalność PINu podczas Zimnej Wojny”, mps.; tamże, korespondencja dotycząca przygotowania zjazdu uczonych polskiego pochodzienia z USA i Kanady.

86 Archiwum PIASA, collection 017, folder 23, „General Report for the period 05.1967-

$8750^{\text {th }}$ Anniversary 1942-1992, s. 39.

${ }^{88}$ Archiwum PIASA, collection 017, folder 24, „General Report for the period 05.1968-

${ }^{89}$ Archiwum PIASA, collection 017, folders 142-146, T. Gromada, „Rola i działalność PINu podczas Zimnej Wojny", mps.
} year 1964" 04.1968". 05.1969". 
księgozbiory i archiwalia opierając się na systemie Biblioteki Kongresu w Waszyngtonie. Problemem było pozyskanie funduszy na ich opracowanie i promowanie ${ }^{90}$.

Rok 1970 przyniósł poprawę sytuacji finansowej, od tego czasu PIASA otrzymywała stałą dotację od Fundacji Jurzykowskiego (od 1968 r. stałe dotacje napływały od Sendzimir Fund) ${ }^{91}$. Od lat 70. XX w. PIASA zaczęła organizować kiermasze książek, na których wyzbywano się dubletów ze zbiorów Instytutu oraz sprzedawano wydawnictwa emigracyjne. Była to istotna działalność, gdyż na Manhattanie nie było wówczas polskiej księgarni ${ }^{92}$. Zorganizowano osiem wykładów, a sześć innych odbyło się w PIASA. Przygotowywano także II Kongres Uczonych Polskiego Pochodzenia z USA i Kanady ${ }^{93}$. Ważnym punktem działalności Instytutu, szczególnie w latach 70. i 80. XX w., były coroczne zjazdy, którym towarzyszyły liczne wykłady i sympozja.

W 1971 r. Polski Instytut Naukowy w Nowym Jorku wziął udział w projekcie „Polish Microfilm” zorganizowanym przez Center for Imigration Studies na University of Minnesota, przy współpracy Fundacji Alfreda Jurzykowskiego i Fundacji Kościuszkowskiej. Projekt miał na celu zachowanie w postaci mikrofilmów dorobku Polonii amerykańskiej $^{94}$. W tym czasie zorganizowano także II Kongres Naukowców, Pisarzy i Artystów Polskiego Pochodzenia z USA i Kanady, odbył się on w dniach 23-25 kwietnia $^{95}$. Na kongres przybyło ponad 500 osób z 76 amerykańskich ośrodków akademickich oraz 20 instytucji badawczych ${ }^{96}$. Pod koniec 1971 r. PIASA zorganizowała dwudniową konferencję, która miała na celu przygotowanie planu do badań nad Polonią Amerykańską jako grupą etniczną ${ }^{97}$. Od tego roku w ramach Instytutu funkcjonowała Sekcja Historyczna. Do 1972 r. (30. rocznicy powołania PIASA) Instytut zorganizował około 350 wykładów, sympozjów, konferencji oraz odczytów ${ }^{98}$. W 1972 r. PIASA rozpoczęła również ścisłą współpracę z American Association for the Advancement Slavic Studies.

Kolejny raz PIASA w 1973 r. otrzymała grant w wysokości 32 tys. dolarów od Rockefeller Foundation na rok 1974. Grant ten miał być przeznaczony na publikację socjologiczno-historyczną opisującą grupę etniczną Amerykanów polskiego pochodzenia. Przyznanie tego grantu świadczyło o wysokim statusie Instytutu oraz postrzeganiu go przez instytucje amerykańskie jako głównego centrum badawczego polskiej emigracji $^{99}$. W tym roku trzech członków PIASA zostało uhonorowanych przez The American Association for the Advancement of Slavic Studies za wkład w badania nad Słowianami. Sekcja Historyczna PIASA zorganizowała spotkanie z Piotrem Wandyczem (doty-

${ }^{90}$ Badacze nie mieli dostatecznej wiedzy o zasobie PIASA, toteż zbiory nie były odpowiednio wykorzystywane; Archiwum PIASA, collection 017, folder 22, „Notatka w sprawie Biblioteki PIN imienia Alfreda Jurzykowskiego z 30.09.1968 r."

91 Archiwum PIASA, collection 017, folder 25, „General Report”.

92 Archiwum PIASA, collection 017, folder 27, „Polski Instytut Naukowy w Ameryce”, s. 21; tamże, „General Report for 1970”.

${ }_{93}$ Archiwum PIASA, collection 017, folder 94, „General Report of Executive Director for 1970 ".

${ }_{94}$ Polish Microfilm Project, The Polish Review 1971 wol. 16 nr 4, s. 93-94.

95 Patrz więcej: Second Congress of Polish American Scholars \& Scientists, New York 1971.

${ }^{96}$ Polski Instytut Naukowy w Ameryce, s. 20.

${ }^{97}$ Plans for Research on Polish American Ethnic Group, The Polish Review, 1972 wol. 17 nr 1, s. 102-103; 50 th Anniversary 1942-1992, s. 41.

${ }^{98}$ Polski Instytut Naukowy w Ameryce, s. 19.

${ }^{99}$ News about the Polish Institute, The Polish Review, 1973 wol. 18 nr 4, s. 118 
czyło badań w Polsce i Czechosłowacji) oraz sympozjum w 200. rocznicę postania Komisji Edukacji Narodowej i 500. rocznicę urodzin Mikołaja Kopernika ${ }^{100}$.

W 1974 r. podjęto wysiłki zmierzające do zintegrowania rozrzuconych po całych Stanach Zjednoczonych członków Instytutu. Rozpoczęto nagrywania wykładów i spotkań organizowanych przez PIASA, aby stworzyć bibliotekę audio dostępną korespondencyjnie dla członków. Wypożyczano także książki, w cyklach tygodniowych. W planach było także utworzenie filmoteki. Dzięki tym działaniom naukowcy i artyści polskiego pochodzenia w całych Stanach Zjednoczonych mieli dostęp do publikacji i informacji naukowej. W ramach Instytutu utworzono w tym czasie: Sekcję Literatury, Sekcję Nauk o Ziemi i Technologii oraz Sekcję Socjologii. Powołano także koła PIASA w Arizonie, Detroit i Filadelfii ${ }^{101}$.

W tym roku Financial Commitee rozpoczął zbieranie funduszy na badania nad Polonią amerykańską. Planowano zebrać około milion dolarów w przeciągu pięciu lat. W tym czasie ruszyły także prace nad grantem od Rockefeller Foundation (z 1973 r. na projekt dotyczący Amerykanów polskiego pochodzenia), zaangażowało się w nie 35 badaczy. Wynikiem tego projektu miało być 15 raportów badawczych, specjalny numer periodyku „International Migration Review” oraz praca zbiorowa The Polish-Americans ${ }^{102}$.

Na zebraniu Zarządu PIASA w kwietniu 1974 r. zdecydowano o istotnej zmianie zakresu i kierunku działalności Instytutu. Szczupłe zasoby finansowe oraz nieliczna kadra kierownicza wymusiły specjalizację i koordynację wysiłków PIASA ${ }^{103}$. Instytut nie był w stanie samodzielnie zajmować się polityką, ekonomią, sztuką, socjologią, edukacją, działalnością wydawniczą i popularyzatorską itp. Kolejne pola działalności PIASA były stopniowo ograniczane na rzecz bardziej wyspecjalizowanych instytucji. PIASA stała się centrum badawczym, jej głównym celem było zdobywanie wiedzy na temat Polonii amerykańskiej (nie prowadzono wcześniej tak szeroko zakrojonych badań nad tą grupą etniczną), prowadzeniu wymiany naukowo-kulturalnej z USA oraz badań nad historią Polski i jej kulturą oraz nauką. Zmieniono również nazwę instytutu na The Polish Institute of Arts and Sciences of America ${ }^{104}$.

Od 1974 r. rozpoczęto także nauczanie języka polskiego w siedzibie Instytutu, kursy trwały do 1990 r. ${ }^{105}$ Przygotowywano również III Kongres Polskich Uczonych z USA i Kanady. Odbył on się w dniach 16-18 maja 1975 r. w Montrealu, wzięło w nim udział około 400 uczestników, w tym około 10 procent spoza USA i Kanady ${ }^{106}$. W swojej dzia-

${ }^{100}$ Archiwum PIASA, collection 017, folder 29, ,Annual Report of The Acting Director and Secretary General April 1972-April 1973".

${ }^{101}$ Polski Instytut Naukowy w Ameryce, s. 20-21.

102 Projekt badawczy składał się z sześciu części, z czego warto nadmienić badania nad: „The Polish Amercans”, „The Polish Experience in Migration” oraz „Community Studies. News About The Polish Institute”; The Polish Review 1974 wol. 19 nr 1, s. 128-129.

${ }^{103}$ Oszczędności uzyskano dzięki zmniejszeniu wynagrodzeń i wydatków oraz podnoszeniu opłaty członkowskiej. Komitet Finansowy Instytutu intensywnie poszukiwał nowych źródeł finansowania jego działalności, podobną inicjatywę podjął nowo wybrany w 1974 r. prezydent PIASA Jan Gronouski; Chronicles of the Polish Institute, The Polish Review 1974 wol. 19 nr 34, s. 237.

${ }^{104}$ Archiwum PIASA, collection 017, folder 31, „New Directions for The Polish Institute of Arts and Sciences in America".

105 Archiwum PIASA, collection 017, folder 31, ,Annual Report of the Executive Director April 1973-April 1974"; 50 ${ }^{\text {th }}$ Anniversary 1942-1992, s. 44.

${ }^{106}$ Archiwum PIASA, collection 017, folder 47, „PIASA Annual Report 1975-1976”. 
łalności PIASA coraz bardziej skłaniała się w kierunku Polonii i amerykańskiego społeczeństwa. Ważnym wydarzeniem dla Instytutu było przyznanie przez Fundację Kościuszkowską grantu na stypendia roczne oraz na projekty badawcze PIASA ${ }^{107}$.

W 1975 r. PIASA wydała rezolucję w obronie 59 polskich intelektualistów, którzy w 1975 r. domagali się gwarancji praw i wolności w nowej konstytucji PRL. Rezolucję tę, w języku angielskim, rozesłano do mediów. Fundacja Kościuszkowska wsparła Instytut 5 tys. dolarów w celu zaproszenia do USA badaczy z Polski, oraz trzema tysiącdolarowymi stypendiami dla bibliotekarzy w Instytucie ${ }^{108}$. W tym roku Oddział PIASA w Kanadzie odłączył się od macierzystej organizacji i utworzył odrębny Polski Instytut Naukowy w Kanadzie. W tym czasie rozpoczęto również starania o granty na projekty „Oral History” oraz „History of Ideas”, które umożliwiłyby opracowanie i reorganizację zbiorów Instytutu. Powołano także Sekcję Biograficzną, której zadaniem miało być zbieranie materiałów dotyczących naukowców i artystów polskiego pochodzenia ${ }^{109}$.

Kolejny rok PIASA czyniła wszelkie wysiłki, mimo corocznych problemów finansowych, aby kontynuować swoją misję w USA, a także by być bardziej widoczną w amerykańskim środowisku akademickim. Instytut zorganizował w 1976 r. 11 wykładów i spotkań, udostępniał swoje zbiory licznym uczonym, a także udzielał pomocy merytorycznej w badaniach naukowych. Członkowie PIASA wzięli udział w ósmej narodowej konwencji American Association for the Advancement of Slavic Studies w październiku 1976 r. W tym roku bardzo doniosłym wydarzeniem dla PIASA była wizyta kardynała Karola Wojtyły. Starano się zaangażować Instytut w problemy społeczeństwa amerykańskiego. Przygotowano w tym celu seminarium „Strategies, Policies for Multi-Ethnic Cities: Focus on New York City"110.

W 1977 r. PIASA ufundowała dwa stypendia dla polskich badaczy, wspierano również studia slawistyczne w różnych ośrodkach akademickich, a także kontynuowano trwającą latami akcję wysyłania książek i periodyków do Polski. W tym czasie powołano także koło PIASA w Teksasie. Zmieniono profil biblioteki, miała ona od tego roku zawierać ograniczony i wyspecjalizowany księgozbiór dotyczący Polski i Polonii, a także zagadnień grup etnicznych w USA ${ }^{111}$. W tym czasie Instytut rozpoczął także zbieranie nagrań (z telewizji, radia oraz wywiadów i wydarzeń naukowo-kulturalnych) dotyczących obrazu Polski i Polaków w USA w ramach „Oral History Project”. Projekt ten, finansowany przez The Rockefeller Foundation, prowadził prof. Feliks Gross. W Instytucie działała specjalna sekcja koordynująca te projekty. Zakończono także prace związane $\mathrm{z}$ grantem na badania nad etniczną grupą Polonii amerykańskiej, wynikiem ich były publikacje w „The Polish Review” oraz tom Polish-American Community Life: a Survey of Research. Projekt ten postanowiono kontynuować wspólnie z Brooklyn College w formie seminarium „Policies, Strategies for Multi-Ethnic Cities: Focus on New York City”" ${ }^{\prime 12}$. Od jesieni 1977 r. zmieniła się również forma rocznych zjazdów PIASA, mniej czasu poświęcano sprawom organizacyjnym, więcej zaś sesjom naukowym i panelom dyskusyjnym ${ }^{113}$.

${ }^{107}$ Chronicles of the Polish Institute, The Polish Review, 1975 wol. 20 nr 1, s. 163.

${ }^{108}$ Chronicles of the Polish Institute, The Polish Review 1976 wol. 21 nr 1-2, s. 179-180.

${ }^{109}$ Polski Instytut Naukowy w Ameryce, s. 29.

${ }^{110}$ Archiwum PIASA, collection 017, folder 34, ,Report of the Secretary General”.

${ }^{111}$ Chronicles of the Polish Institute, The Polish Review 1977 wol. 22 nr 1, s. 80-81; Archiwum PIASA, collection 017, folder 35, „Unowocześnienie Biblioteki PIN”.

112 Chronicles of the Polish Institute, The Polish Review 1977 wol. $22 \mathrm{nr}$ 1, s. 86-89.

${ }^{113} 50^{\text {th }}$ Anniversary 1942-1992, s. 49. 
W roku 1978 zainteresowanie badawcze problemami etnicznymi w USA znacznie zmalało. Wiele czynników, w tym bezrobocie, inflacja oraz sytuacja międzynarodową, wpłynęło na zmniejszenie zainteresowania tą gałęzią badań naukowych. PIASA zakończyła ostatecznie badania nad społecznościami Polonii Amerykańskiej, realizowane w ramach grantu The Rockefeller Foundation. Przy wsparciu tejże fundacji uruchomiono kolejny program badawczy dotyczący historii mówionej oraz historii idei. The Rockefeller Foundation przeznaczyła także pieniądze na katalogowanie i porządkowanie zbiorów Instytutu. Wsparcie Fundacji Alfreda Jurzykowskiego pozwoliło utrzymać budynek oraz zbiory Instytutu, zaś pomoc Fundacji Kościuszkowskiej wraz z Sendzimir Fund zapewniła środki na jego działalność. PIASA otrzymała dziesięcioletni grant na badania nad wymianą kulturową od Fundacji Kościuszkowskiej ${ }^{114}$.

PIASA nawiązała również ścisłą współpracę z Towarzystwem Historyczno-Literackim w Paryżu oraz Biblioteką Polską. Rozpoczęto wspólne zbieranie funduszy na działalność tych instytucji wśród europejskich fundacji. Biblioteka Polska udostępniła także swoje zbiory dla badaczy poleconych przez PIASA, podobną współpracę podjęto z Instytutem im. gen. W. Sikorskiego w Londynie. Współpraca ta zaowocowała przekazaniem i wymianą zbiorów archiwalno-bibliotecznych ${ }^{115}$.

Rok 1979 był czasem znacznego wzrostu działalności Instytutu, intensyfikacji uległa praca wydawnicza, naukowo-badawcza oraz popularyzatorska (zorganizowano aż 19 wykładów i konferencji) ${ }^{116}$. Wsparcie Fundacji Alfreda Jurzykowskiego (również Sendzimir Fund) pozwoliło na reorganizację i odpowiednie wyposażenie rozrastającej się biblioteki. Jej bogaty księgozbiór pozwalał licznym specjalistom na niezależne badania naukowe. W latach 70. XX w. PIASA stała się jednym z największych ośrodków biblioteczno-archiwalnych w USA. Fundacja Kościuszkowska zapewniła trzy pięćsetdolarowe stypendia dla studentów pracujących w PIASA. The Rockefeller Foundation dostarczyła pieniądze na pracę nad zasobem archiwalnym Instytutu oraz projektem związanym z historią mówioną i historią idei. Rosenstiel Foundation i Fundacja Kościuszkowska przeznaczyły dziesięcioletnie granty wspierające budżet PIASA ${ }^{117}$. W 1979 r. dwóch członków PIASA - Isaac Bashevis Singer oraz Andrew Shally otrzymało Nagrodę Nobla, zaś Ludwik Gross za badania nad białaczką został nagrodzony przez rząd Francji oraz Republiki Federalnej Niemiec.

W 1980 r. granty od Fundacji Kościuszkowskiej oraz The Rockefeller Foundation pozwoliły na dalsze badania nad wymianą kulturową emigracji. PIASA utrzymywała także żywe kontakty z centrami badawczymi w Europie, Kanadzie, Ameryce Południowej oraz Australii. Dzięki zatrudnieniu Witolda Sulimirskiego jako skarbnika, finanse Instytutu były należycie zarządzane. PIASA otrzymała także wsparcie prawnicze od Ludwika Seidenmana. Dalsze funkcjonowanie PIASA (w tym prace nad „Oral History Project"), stypendia oraz utrzymanie zbiorów archiwalno-bibliotecznych zapewniły fundusze od: The Rockefeller Foundation, Rosenstiel Foundation, Fundacji

${ }^{114}$ Chronicles of the Polish Institute, The Polish Review 1978 wol. 23 nr 2, s. 93-94, 97; Archiwum PIASA, collection 017, folder 38, „Report of the Secretary General April 1978March 1979",

${ }_{115}$ Chronicles of the Polish Institute, The Polish Review 1978 wol. 23 nr 2, s. 95.

${ }^{116}$ Archiwum PIASA, collection 017, folder 40, ,Annual Report of Secretary General April 1979-1980".

${ }^{117}$ Chronicles of the Polish Institute, The Polish Review 1979 wol. 24 nr 2, s. 107-112. 
Kościuszkowskiej oraz Sendzimir Fund. W tym roku ukończono prace nad tomem Polish Civilisation: Essays and Studies, wydanym przez New York University Press ${ }^{118}$.

Wydarzenia w Polsce w latach 1980-1989 miały istotny wpływ na działalność PIASA. Pod koniec 1980 r. powołano Komitet Pomocy Naukowcom z Polski. Po wprowadzeniu stanu wojennego w Polsce 13 grudnia 1981 r. PIASA potępiła publicznie działania gen. W. Jaruzelskiego, zaś Sekretarz Generalny Instytutu prof. T. Gromada przesłał swoje wystąpienie w tej sprawie do Prezydenta USA, Sekretarza Stanu, Rady Bezpieczeństwa oraz mediów amerykańskich. Wystąpienie to zostało wyemitowane przez Radio Wolna Europa oraz Voice of America ${ }^{119}$. W tak trudnym dla Polski momencie uwidoczniła się bardzo ważna rola Instytutu, wielu przedstawicieli mediów amerykańskich zwracało się do PIASA z prośbą o udzielenie informacji i komentarzy na temat sytuacji w kraju ${ }^{120}$.

W stanie wojennym Instytut starał się wspierać polskich uczonych, którym wydarzenia w kraju uniemożliwiły powrót i poszukiwali azylu w USA ${ }^{121}$. Było to możliwe dzięki funduszom od The Rockefeller Foundation oraz organizacji IREX ${ }^{122}$. Siedziba Instytutu stała się miejscem, w którym wiele osób szukało finansowego i moralnego wsparcia. Przy wsparciu PIASA powołano Special Counselling and Academic Assistance Committee, który miał za zadanie zapewnić pomoc prawną, informować o stypendiach oraz o możliwości znalezienia zatrudnienia w USA ${ }^{123}$. Przymusowym emigrantom przyznawano niewielkie granty, część otrzymywała rekomendacje na studia. Od 1981 r. PIASA współpracowała z National Endowment for Democracy przy udzielaniu pomocy członkom Solidarności ${ }^{124}$. Zbierano także intensywnie fundusze na zakup książek i periodyków dla polskich uczelni i bibliotek. W latach 70. i 80. XX w. członkowie PIASA byli częstymi gośćmi na tzw. briefingach w Białym Domu i Departamencie Stanu, gdzie służyli swoimi radami. W tym czasie również kolejni przedstawiciele dyplomatyczni USA, kierowani do Polski, przed wylotem odwiedzali PIASA $\mathrm{w}$ celu odbycia konsultacji związanych $\mathrm{z}$ ich misją ${ }^{125}$.

W 1981 r. wysiłki PIASA skupiały się na pracy na gruncie kulturalno-naukowym oraz służeniu jako polsko-amerykańskie centrum badawcze. Swoją pracą wśród amerykańskiego społeczeństwa wspierała opozycję demokratyczną w Polsce. Podobnie jak w poprzednich latach funkcjonowanie PIASA, stypendia oraz utrzymanie zbiorów archiwalno-bibliotecznych zapewniły fundusze od: The Rockefeller Foundation, Rosenstiel Foundation, Fundacji Kościuszkowskiej oraz Sendzimir Fund. Instytut otrzymał kolejny raz pieniądze od The Rockefeller Foundation na badania nad kwestiami etnicznymi oraz opozycją demokratyczną w Polsce w ramach projektu „Oral History”. Ogromną pomoc (zbiory zostały uszkodzone przez wodę) dla utrzymania zbiorów

${ }^{118}$ Chronicles of the Polish Institute, The Polish Review 1980 wol. 25 nr 3-4, s. 150-153, 161.

$11950^{\text {th }}$ Anniversary 1942-1992, s. 50-51. Również dzięki wysiłkom Thaddeusa Gromady udało się Instytutowi nawiązać bliższą współpracę z amerykańskimi kręgami akademickimi, a także zmienić formę corocznych zjazdów PIASA.

${ }^{120}$ Tamże, s. 54.

${ }^{121}$ Archiwum PIASA, collection 017, folder 105, „Minutes of the Board of Directors 1981”.

$12250^{\text {th }}$ Anniversary 1942-1992, s. 54. IREX - organizacja non-profit powstała w USA w 1968 r., wspierająca badania naukowe oraz działalność kulturalną.

${ }^{123}$ Tamże.

${ }^{124}$ Wiodącą rolę w nawiązaniu przez PIASA współpracy z National Endowment for Democracy odegrał Feliks Gross.

125 Archiwum PIASA, collection 017, folders 142-146, T. Gromada, „Rola i działalność PINu podczas Zimnej Wojny", mps. 
archiwalnych stanowił grant od National Endowment for the Humanities ${ }^{126}$. Udało się także opracować przy wsparciu konsultanta ds. archiwalnych z City University of New York kryteria opracowania materiałów archiwalnych oraz przygotować spis zespołów. Wyznaczono także pracowników i wolontariuszy odpowiedzialnych za opracowanie zbiorów archiwalnych ${ }^{127}$.

W 1982 r. w związku z sytuacją w Polsce zwiększono ilość wysyłanych do kraju książek i periodyków, Instytut gościł większą liczbę badaczy z Polski, nawiązano obiecujący dialog między emigracyjną a krajową nauką. Wszystko to przekreśliło wprowadzenie stanu wojennego w Polsce, co spotkało się z ostrą reakcją ze strony członków PIASA. Deklaracja Zarządu Instytutu, wyrażająca sprzeciw wobec ograniczeniu swobód Polaków, została opublikowana w amerykańskich mediach. W społeczeństwie amerykańskim wzrosło zainteresowanie wypadkami w Polsce, wobec czego PIASA miała możliwość zabrania kolejny raz głosu w obronie wolnej Polski. Kolejne roczne granty od The Rockefeller Foundation, Rosenstiel Foundation, Fundacji Kościuszkowskiej oraz Sendzimir Fund umożliwiły dalszą wydatną pracę Instytutu. Stan wojenny uniemożliwił powrót do kraju wielu badaczom przebywającym w USA. PIASA podjęła natychmiastową akcję niesienia pomocy materialnej ,,przymusowym” emigrantom ${ }^{128}$.

W 1983 r. po 40 latach istnienia Instytut stał się częścią amerykańskiej kultury i nauki, jednocześnie reprezentując wolną Polskę i jej dorobek w wielu dziedzinach życia. Działalność PIASA była ukierunkowana na obronę praw człowieka w Polsce, protestowano w amerykańskich mediach, kierowano odezwy do amerykańskiego społeczeństwa ${ }^{129}$. Zwracano się także do amerykańskich ośrodków akademickich z prośbą o poparcie żądania wolności naukowej i obrony uczonych w Polsce. Powołano także specjalny Committe on Human Rights, kwestia pogwałcenia praw człowieka w Polsce została przez PIASA przedstawiona The International Legue for Human Rights. Dzięki donacjom Instytut mógł za 2 tys. dolarów nabyć i wysłać książki do Warszawy. Dyrektor PIASA zainicjował powstanie funduszu dla polskich bibliotek. Otrzymano stałe wsparcie finansowe od The Rockefeller Foundation, Rosenstiel Foundation, Fundacji Kościuszkowskiej oraz Sendzimir Fund. Prowadzono liczne badania naukowe, w tym dwa duże projekty dotyczące Bronisława Malinowskiego oraz historii ideologii. Ukończono także edycję pierwszego przewodnika po zbiorach PIASA, który ukazał się w 1984 r. $^{130}$

W kolejnym roku głównym polem działania PIASA była w dalszym ciągu obrona praw człowieka w Polsce. Wydarzenia w kraju były bacznie obserwowane i komentowane przez członków PIASA, zaprezentowano memorandum w sprawie sytuacji w Polsce przed Komitetem Praw Człowieka w Genewie. Wystosowano również wiele protestów wobec aresztowań i przetrzymywania w więzieniach polskich naukowców $\mathrm{i}$ artystów, zostały one opublikowane w prasie amerykańskiej oraz w Radiu Wolna Europa. PIASA zwróciła się także do prezydenta USA Ronalda Reagana z prośbą o ułatwienie otrzymania wizy i legalizacji pobytu dla przymusowych emigrantów z Polski. Instytut zajmował się również relacjami polsko-ukraińskimi i żydowskimi,

\footnotetext{
${ }^{126}$ Chronicles of the Polish Institute, The Polish Review 1981 wol. 26 nr 2, s. 88-91, 94.

127 Polski Instytut Naukowy w Ameryce, s. 34.

${ }^{128}$ Chronicles of the Polish Institute, The Polish Review 1982 wol. 27 nr 1-2, s. 187-191; $50^{\text {th }}$ Anniversary 1942-1992, s. 55.

${ }^{129}$ Archiwum PIASA, collection 017, folder 106, ,Minutes of the Board of Directors year 1983".

${ }^{130}$ Chronicles of the Polish Institute, The Polish Review 1983 wol. 28 nr 2, s. 129-137.
} 
dążąc do przezwyciężenia uprzedzeń i poprawy wzajemnych stosunków. Duży wysiłek włożono w opracowanie i zabezpieczenie zbiorów archiwalno-bibliotecznych ${ }^{131}$.

W 1985 r. Instytut, jako część New York Nonprofits, wystąpił wraz z innymi organizacjami typu nonprofit $\mathrm{w}$ obronie amerykańskich instytucji kulturalnych i naukowych. Kwestia zwolnienia tych instytucji od podatków od nieruchomości miała kluczowe znaczenia dla ich przetrwania ${ }^{132}$. Konieczność opuszczenia siedziby PIASA przy 66 Ulicy spowodowała zamknięcie archiwum i biblioteki, kolekcje zostały spakowane i przekazane do wynajętych magazynów. Rozpoczęto przygotowania do wydania drugiego przewodnika po zasobie Instytutu ${ }^{133}$.

Kolejny rok był ciężki dla PIASA, Fundacja Alfreda Jurzykowskiego zdecydowała się sprzedać dom na 66 Ulicy, który był siedzibą Instytutu. Cała działalność PIASA skupiła się na zabezpieczeniu i przewiezieniu zbiorów Instytutu do tymczasowej siedziby w Fundacji Kościuszkowskiej, jak również poszukiwaniu nowej siedziby. Rozpoczęto zbiórkę funduszy na zakup nowego budynku w Nowym Yorku. Mimo tak trudnej sytuacji PIASA, choć w ograniczonym stopniu, kontynuowała swoją działalność. Utrzymano wydawanie „The Polish Review”, prowadzono dalej wykłady, a nawet zorganizowano w listopadzie 1985 r. konferencję „Transition of Medieval and Early Modern Polish Elites"134. W latach 1985-1986 udało się zorganizować także 11 wykładów i spotkań ${ }^{135}$. Zakończono pierwszą część badań nad historią idei, wynikiem ich była publikacji Political Ideas of the Democratic Left of the Polish Emigration, 1939-1968. Zarząd Instytutu wydał również list protestacyjny w obronie autonomii uniwersytetów w Polsce, został on ogłoszony w amerykańskim radiu ${ }^{136}$. Praktycznie cały 1986 r. upłynął na zadaniach związanych z zakupem nowej siedziby i przeprowadzką oraz zabezpieczeniem zbiorów PIASA ${ }^{137}$.

W 1987 r. dzięki wsparciu Fundacji Kościuszkowskiej Instytut mógł realizować, poza przeprowadzką i zabezpieczeniem archiwaliów i biblioteki, część swoich zadań w tymczasowej siedzibie na 65 Ulicy $^{138}$. Zakupiono nową siedzibę dla PIASA na 30 Ulicy, gdzie przewieziono część zbiorów (były one niedostępne dla badaczy od 1985 do 1987). Od tego roku intensywnie poszukiwano funduszy na spłatę kredytu zaciągniętego na zakup budynku oraz jego wyposażenie ${ }^{139}$. Opublikowano dwie prace będące efektem wcześniejszych badań: Polish Democratic Left 1940-1968 oraz Christian Democratic Groups, 1940-1968. Przygotowano także trzeci tom Letters From the Underground $^{140}$. Fundusze pochodzące od organizacji, które od lat wspierały PIASA, posłużyły do sfinansowania przeprowadzki i wyposażenia nowej siedziby, a także na stypendia i działalność bieżącą PIASA ${ }^{141}$.

\footnotetext{
${ }^{131}$ Chronicles of the Polish Institute, The Polish Review 1984 wol. 29 nr 3, s. 125-135.

${ }^{132}$ Polski Instytut Naukowy w Ameryce, s. 22.

${ }^{133} 50^{\text {th }}$ Anniversary 1942-1992, s. 55.

${ }^{134}$ Tamże, s. 56.

135 Archiwum PIASA, collection 017, folder 43, „Annual Report of the Secretary General May 1985-May 1986".

${ }^{136}$ Chronicles of the Polish Institute, The Polish Review 1986 wol. 31 nr 2-3, s. 227-236; Archiwum PIASA, collection 017, folder 43, „PIASA Annual Report 1985-1986”.

${ }^{137}$ Archiwum PIASA, collection 017, folder 43, „PIASA Annual Report 1985-1986”.

${ }^{138} 50^{\text {th }}$ Anniversary 1942-1992, s. 56.

${ }^{139}$ Tamże, s. 57.

${ }^{140}$ Archiwum PIASA, collection 017, folder 43, „PIASA Annual Report 1985-1986”.

${ }^{141}$ Chronicles of the Polish Institute, The Polish Review 1987 wol. 32 nr 3, s. 330-337.
} 
Po dwóch latach kryzysu, w 1988 r., działalność Instytutu osiągnęła wcześniejszy poziom i zasięg. Wsparcie dla Instytutu było szersze wśród amerykańskiego społeczeństwa, a jego sytuacja finansowa dzięki spłacie kredytów i lepszemu gromadzeniu funduszy uległa poprawie. W celu usprawnienia działalności PIASA powołano specjalne komitety: Fund-Raising Committee, Committee on By-laws, Special Events Committee oraz Self-Study Committee. Wewnętrzna organizacja oraz praca bieżąca PIASA zostały poddane analizie i zreorganizowane, dzięki zaangażowaniu nowych członków. Starano się poprawić sytuację materialną, wydajność pracy oraz podnieść poziom naukowy badań. Instytut miał stanowić, jako stowarzyszenie niezależnych naukowców i artystów, pomost między polskim a amerykańskim światem nauki i kultury, a także służyć jako centrum edukacyjne. PIASA, aby osiągać podobny respekt i pozycję co amerykańskie organizacje, musiała zwiększać liczbę członków oraz utrzymywać najwyższy poziom badań naukowych. W tym czasie prof. Feliks Gross udzielił sześciu wywiadów w Radiu Wolna Europa na temat badań nad historią idei w Polsce. Dzięki grantowi Fundacji Alfreda Jurzykowskiego w wysokości 6 tys. dolarów, zakupiono liczne książki dla Uniwersytetu Jagiellońskiego. Kolejni stypendyści, dzięki pieniądzom z Fundacji Kościuszkowskiej, mogli pracować nad katalogowaniem i porządkowaniem zbiorów PIASA $^{142}$.

W kolejnym roku sytuacja materialna PIASA uległa dalszej poprawie. Powołano specjalny Committee on Publication of Books, ukazała się także bardzo istotna publikacja The Polish Renaissance in its European Context. Instytut stopniowo przekształcał się z instytucji naukowej zrzeszającej wybranych uczonych w kulturalną i edukacyjną organizację skupiającą stałych członków i osoby zaprzyjaźnione. Cel działalności Instytutu nie został zmieniony. Najważniejszymi polami działalności Instytutu było: wydawanie „The Polish Review”, organizowanie wykładów i seminariów, pozyskiwanie księgozbiorów i archiwaliów oraz zabezpieczanie funduszy na dalszą działalność PIASA $^{143}$.

W 1989 r. transformacja, która rozpoczęła się w Polsce, miała istotny wpływ na pracę Instytutu. PIASA powołana 47 lat temu była symbolem i centrum wolnej i niepodległej kultury i nauki polskiej na emigracji, która z czasem stała się instytucją amerykańską (choć powołaną przez polskich emigrantów). Wraz z upadkiem PRL ośrodki badawcze i kulturalne uwolniły się spod wpływu ideologii komunistycznej i cenzury. Tym samym podstawowy cel PIASA, reprezentowania i rozwijania niezależnej nauki i sztuki w USA, został osiągnięty. Pozostało pytanie co do dalszej działalności, wciąż aktualnymi były cele edukacyjne i kulturalne ${ }^{144}$. Od tego czasu głównym zadaniem PIASA była wymiana kulturowa i naukowa między Polską a USA, jak również wspieranie badań nad zagadnieniami związanymi z Polską oraz popularyzacja wiedzy o niej.

W tym czasie PIASA zaangażowała się w wydanie mów Abrahama Lincolna w Polsce, prof. Feliks Gross przedstawił również serię wykładów o Konstytucji USA w Radiu Wolna Europa. Pieniądze od Sendzimir Fund, Fundacji Kościuszkowskiej, National Endowment for Democracy oraz Alfred Jurzykowski Foundation były w większości przeznaczone na stypendia dla polskich badaczy. Członkowie PIASA wzięli udział w trzecim Kongresie Uczonych Polskiego Pochodzenia w lipcu 1989 r. W rocznicę rozpoczęcia kampanii wrześniowej 1939 r. zorganizowano akcję „Salute to Poland". Wydano pracę Samuela Fiszmana (wstęp Czesław Miłosz) The Polish Renais-

\footnotetext{
${ }^{142}$ Chronicles of the Polish Institute, The Polish Review 1988 wol. 33 nr 3, s. 379-383.

${ }^{143}$ Chronicles of the Polish Institute, The Polish Review 1989 wol. 34 nr 3, s. 276-282.

${ }^{144}$ Chronicles of the Polish Institute, The Polish Review 1989 wol. 35 nr 3, s. 303-304.
} 
sance in Its European Context. Nawiązano ściślejsze stosunki z ośrodkami akademickimi w Polsce. Prowadzono nadal kursy języka polskiego, od 1982 r. organizowane wspólnie z Fundacją Kościuszkowską i Hunter College ${ }^{145}$.

Polski Instytut Naukowy w Ameryce został założony przez polskich naukowców, którzy znaleźli się na emigracji w USA, uniknąwszy śmierci i prześladowań z rąk okupantów. W chwili powstania był on kontynuacją Polskiej Akademii Nauk oraz symbolem wolnej kultury oraz myśli naukowej. Przechodził w latach 1942-1989 wiele przemian, zaczynał swoją działalność jako emigracyjne towarzystwo naukowo-kulturalne, zaś do roku 1989 stał się organizacją o ogólnoamerykańskim zasięgu. Emigracyjne organizacje nie cieszyły się zbytnią renomą w amerykańskim świecie akademickim, dlatego ważną rzeczą była zmiana wizerunku PIASA. Od lat 60. XX w. jego członkami zostawali Polacy urodzeni w USA oraz Amerykanie związani swoimi badaniami naukowymi z Polską ${ }^{146}$.

W krótkim czasie od powstania Instytut stał się uznanym, wśród amerykańskich i europejskich badaczy, centrum naukowo-kulturalnym. W czasie II wojny światowej w PIASA skupiało się wolne życie naukowo-kulturalne, w warunkach zachodniej demokracji. Rok 1945 przyniósł wielkie rozczarowanie powojenną rzeczywistością, a Polska stała się de facto kolonią ZSRR. W obliczu powojennych przemian celem istnienia Instytutu stało się kontynuowanie wolnego życia naukowego i kulturalnego na obczyźnie oraz praca dla przyszłości Polski (poprzez obronę wolności i praw człowieka oraz publiczne protesty wobec działań władz komunistycznych w kraju). W okresie zimnej wojny (dla Polski można przyjąć lata 1946-1989) PIASA odgrywała rolę ośrodka informacyjnego i naukowego niezależnego od władz PRL. Starano się również pokazać społeczeństwu amerykańskiemu, iż Polska nie jest komunistycznym państwem wrogim Stanom Zjednoczonym. Instytut propagował wiedzę o Polsce i jej dziedzictwie naukowym i kulturalnym, brał również czynny udział w podtrzymaniu współpracy polsko-amerykańskiej. Było to szczególnie istotne w momentach przełomowych, kiedy wzrastało zainteresowanie sprawami polskimi wśród społeczeństwa oraz w mediach amerykańskich. Przez lata Instytut cieszył się wsparciem finansowym umożliwiającym jego działanie od m.in.: The Kościuszko Foundation, Alfred Jurzykowski Foundation, Rockefeller Foundation, Alfred Sloane Foundation, Sendzimir Found, National Endowment for Humanities i National Endowment for Democracy oraz osób prywatnych $^{147}$

Zawsze jednak Instytut występował w obronie wolnej nauki i sztuki oraz praw człowieka w Polsce. Przez lata PIASA wspierała polskie ośrodki naukowo-badawcze wysyłając książki i periodyki, sprzęt medyczny i laboratoryjny. Fundowano stypendia i granty dla polskich uczonych i artystów. Udzielano wywiadów oraz wygłaszano wykłady za pośrednictwem Radia Wolna Europa, które stanowiły wsparcie moralne dla zniewolonej Polski. Instytut był forum wolnej wymiany myśli otwartym dla naukowców, artystów i studentów. Odwiedzało go również wielu wybitnych Polaków, dla których organizowano spotkania, wykłady itp. ${ }^{148}$

\footnotetext{
145 Tamże, s. 305-328.

146 50th Anniversary Polish Institute of Arts \& Sciences of America, New York 1992, s. 18.

${ }^{147}$ Tamże, s. 19-21.

${ }^{148}$ M.in.: kardynał Karol Wojtyła, Wacław Sierpiński, Julian Krzyżanowski, Irena Sławiń-
} ska, Jacek Woźniakowski, Władysław Tatarkiewicz, Sławomir Mrożek, Aleksander Gieysztor, Antoni Słonimski, Jerzy Turowicz, Tadeusz Konwicki, Leopold Tyrmand, Józef Gierowski, 
Wobec przemian w Polsce w 1989 r. PIASA kolejny raz stanęła przed koniecznością dostosowania się do nowej sytuacji politycznej. Zaistniały nowe możliwości do rozwoju PIASA oraz do poszerzenia pola działalności. Dopiero od 1989 r. PIASA mogła nawiązać właściwe stosunki z polskim światem naukowym i kulturalnym. Po restytucji Polskiej Akademii Nauk w Polsce w 1989 r. PIASA nawiązała bliskie kontakty z odtworzoną akademią. Instytut stał się symboliczną siedzibą i stacją PAU w Nowym Jorku. Nawiązano również owocne stosunki z wieloma instytucjami w Polsce, w tym m.in. z Polską Akademią Nauk, Naczelną Dyrekcją Archiwów Państwowych, Biblioteką Narodową itd. Po 1989 r. rozpoczął się nowy okres działalności w dziejach Instytutu, w którym całą uwagę skierowano na współpracę polsko-amerykańską w wielu dziedzinach życia naukowego i kulturalnego. PIASA służyła jako centrum kulturalno-badawcze dla Polski i USA, stanowiła pomost łączący i wzbogacający obydwa społeczeństwa. Dzięki pracy PIASA możliwe było zaznaczenie polskiej obecności w demokratycznym zachodnim świecie ${ }^{149}$.

Aleksander Koj, ks. Józef Tischner, Jan Błoński, Stanisław Waltoś, Władysław Bartoszewski, Tadeusz Kantor, Tadeusz Różewicz, Ryszard Kapuściński, Stanisław Barańczak, Rafał Olbiński, Andrzej Ajnenkiel, Tadeusz Mazowiecki i inni; Archiwum PIASA, collection 017, folders 142146, T. Gromada, ,Rola i działalność PINu podczas Zimnej Wojny”, mps.

${ }^{149}$ 50th Anniversary Polish Institute of Arts \& Sciences, s. 22. 


\section{ANEKS}

Lista pracowników PIASA w latach 1942-2011

Prezesi PIASA:

Prof. dr Bronisław Malinowski 1942;

Prof. dr Jan Kucharzewski 1942-1952;

Prof. dr Oskar Halecki 1952-1964;

Zygmunt Nagórski, Senior 1964-1965;

Prof. dr Stanisław Mrozowski 1965-1974;

Prof. dr John A. Gronouski, 1974-1987;

Prof. dr Feliks Gross, 1988-1999;

Prof. dr Piotr S. Wandycz, 1999-2008;

Prof. dr Thaddeus V. Gromada, 2008-2011.

Dyrektorzy wykonawczy:

Prof. dr Oskar Halecki, 1942-1952;

Zygmunt Nagórski, senior, 1952-1955;

Stanisław Strzetelski, 1955-1961;

Zygmunt Nagórski, 1961-1962;

Dr Jan Wszelaki, 1962-1965;

Damian Wandycz, 1966-1969;

Dr Jan Librach, 1969-1973;

Prof. dr Eugene Kleban, 1973-1975;

Prof. dr Feliks Gross, 1975-1988;

Bolesław Laszewski, 1989-1990;

Prof. dr Thaddeus V Gromada, 1991-2011.

Sekretarze generalni:

Zygmunt Nagórski, senior, 1957-1964;

Damian Wandycz 1965;

Dr Ludwik Krzyżanowski, 1966-1970;

Prof. dr Thaddeus V Gromada, 1971-1990.

\section{THE ACTIVITY OF THE POLISH INSTITUTE OF ARTS AND SCIENCES}

The Polish Institute of Arts and Sciences in America was established by Polish scientists who found themselves on emigration in the USA as a result of World War II. At the moment of its origin, it was the continuation of the Polish Academy of Sciences as well as the symbol of free culture and scientific thought. It underwent many transformations in the years 1942-1989, it started its activity as the emigration scientific-cultural society, by 1989 it became an organisation of all-American scope. The article is an attempt to describe the activity of that most important Polish scientific centre in the United States from the perspective of research output, biographies of its creators and contributors and the role it played in the Polish and American science in the years 1942-1989. Special attention was paid to the publications, including The Polish Review journal, and books published in English, which joined the world science canon about Poland and Middleand Eastern Europe in the field of history, literary and social sciences.

KEY WORDS: Polish science on emigration; R. Taubenschlag; O. Halecki; J. Kucharzewski; W. Lednicki; B. Malinowski; Polish Institute of Arts and Sciences in America; Polish scientific institutions in America.

(m.sz.) 